\title{
PENGEMBANGAN MULTIMEDIA PEMBELAJARAN INTERAKTIF MATA KULIAH SENI LUKIS I JURUSAN SENI RUPA
}

\author{
Ferry Affandi Pangaribuan dan Abdul Hasan Saragih \\ FBS Universitas Negeri Medan dan PPs Universitas Negeri Medan \\ ferry.affandi@gmail.com
}

\begin{abstract}
Abstrak: Penelitian ini bertujuan untuk menghasilkan media pembelajaran berupa produk Multimedia Pembelajaran Interaktif berdasarkan kriteria kualitas media pembelajaran yang valid serta untuk melihat efektifitas dalam pembelajaran seni lukis I. Penelitian ini menggunakan desain penelitian dan pengembangan. Subjek penelitian adalah mahasiswa jurusan seni rupa semester III yang sedang mengikuti mata kuliah seni lukis I. Data diperoleh melalui observasi, wawancara, kuesioner dan dokumentasi. Analisis data menggunakan uji t dan deskriptif. Uji efektivitas produk dilakukan melalui validasi ahli, uji coba perorangan, uji coba kelompok kecil, dan uji coba lapangan dan test hasil belajar. Hasil penelitian ini adalah terciptanya media pembelajaran interaktif seni lukis I dalam bentuk keping DVD yang dilengkapi dengan teks penjelasan materi dan video peraga yang dapat digunakan pada PC atau laptop dan dapat dilakukan tanpa menginstall program flash terlebih dahulu karena file utama disajikan dalam ekstensi.
\end{abstract}

Kata Kunci: pengembangan multimedia, pembelajaran interaktif, mata kuliah seni lukis I

Abstract: This research was aimed to: produce a learning media Multimedia Interactive Learning products based on quality criteria for a valid instructional media and to see the effectiveness of the learning painting I. This study used a design research and development . Subjects were students majoring in art who are following the third semester course painting I. The data obtained through observation, interviews, questionnaires and documentation. Data analysis using t-test and descriptive. Test the effectiveness of the product is done through expert validation, individual testing, small group testing, and field trials and test learning outcomes . The results of this research is the creation of interactive learning media painting I in the form of a DVD that comes with explanatory text and video display materials that can be used on a PC or laptop and can be done without first installing the flash program as presented in the main file extensions .

Keywords: multimedia development, interactive learning, painting subjects I

\section{PENDAHULUAN}

Proses perkembangan alat bantu pembelajaran sangat mempengaruhi pembelajaran. Bila kita lihat perkembangan alat bantu pembelajaran yang sering disebut media pembelajaran, awalnya dikenal melalui suatu gerakan dalam dunia pendidikan dinamakan "visual educational", dimana guru harus menggunakan gambar-gambar untuk memperjelas apa yang diajarkannya. Setelah media visual berkembang secara cepat dengan berbagai modifikasi dari kreasi setiap generasi maka muncullah media audio yang disebut gerakan "audiovisual education" yang menekankan pentingnya penggunaan audio visual dalam pembelajaran. Disinilah mulai dikenal Audio Visual Aids (AVA) yaitu alat peraga yang menyajikan bahan-bahan visual dan audio untuk memperjelas apa yang disampaikan pengajar kepada peserta didik disebut juga "Teaching Aids". Perkembangan berikutnya terciptalah suatu model komunikasi untuk kegiatan elektronika sehingga munculah istilah "Audiovisual Communication". Selanjutnya muncul istilah "Educational Communication" dan kemudian "Educational Media" semuanya menampilkan fungsi baru yaitu komunikasi dalam penggunaan media.

Teori komunikasi mulai mempengaruhi penggunaan alat bantu audio visual, sehingga selain sebagai alat bantu media juga berfungsi sebagai penyalur pesan atau informasi belajar. Semenjak saat itu audio visual bukan hanya dipandang sebagai alat bantu guru saja, melainkan juga sebagai alat penyalur pesan atau media dalam pembelajaran. Penelitian mulai memperhatikan peserta didik sebagai komponen yang penting dalam proses belajar mengajar. 
Pada saat itu teori tingkah laku mulai mempengaruhi penggunaan media dalam kegiatan pembelajaran. Media pembelajaran yang terkenal dihasilkan teori ini adalah teaching machine dan programmed instruction. Media pembelajaran berkembang lagi dengan pendekatan sistem (system approach) yang mulai menampakkan pengaruhnya dalam kegiatan pembelajaran. Dimana setiap program pembelajaran harus direncanakan secara sistematis dengan memusatkan perhatian kepada peserta didik serta direncanakan berdasarkan kebutuhan dan karakteristik peserta didik sesuai dengan tujuan yang akan dicapai.

Pemanfaatan alat bantu komunikasi makin berkembang pesat, terutama media berbasiskan komputer dimana komputer bukan lagi sekedar berbasiskan audio visual tetapi juga sentuhan (touching) yang lebih menekankan pada intraksi langsung antara penyampai pesan, media, serta penerima pesan. Dari sini lahirlah konsep penggunaan multimedia dalam kegiatan pembelajaran yang lebih terfokus pada interaktivitas antara media dengan pemakai media. Dimana multimedia digunakan sebagai penyampaian informasi secara interaktif dan terintegrasi yang mencakup teks, gambar, suara, video atau animasi, serta hypermedia dan hypertext termasuk multimedia interaktif berbasis komputer. Ada juga mengatakan multimedia merupakan media yang menggabungkan dua unsur atau lebih media yang terdiri dari teks, grafis, gambar, foto, audio, video dan animasi secara terintegrasi. Sehingga multimedia terbagi menjadi dua kategori, yaitu: Multimedia linier dan Multimedia interaktif.

Berdasarkan pengamatan yang dilakukan pada Jurusan Seni Rupa Fakultas Bahasa dan Seni Universitas Negeri Medan (FBS UNIMED) menunjukkan bahwa para mahasiswa membutuhkan media pembelajaran mutakhir. Hal ini disebabkan, mahasiswa lebih dapat menangkap materi melalui rangsangan menggunakan panca indra, baik dari bentuk objek benda, data maupun peristiwa kemudian memperhatikan atau mengabaikan, memilih sebagian atau menerima seluruhnya, dan membuat reaksi dengan membuat respon respon visual yang mereka apresiasikan kedalam bentuk kekaryaannya. Dari pengamatan dapat disimpulkan bahwa pengajar membutuhkan media pembelajaran mutakhir dalam proses pembelajaran agar proses pembelajaran berjalan lebih efektif. Hasil wawancara dengan dosen pengampu. Seni Lukis I menunjukkan bahwa pembelajaran selama ini dilakukan dengan metode ceramah, menunjukkan buku teks dan gambar gambar dengan menggunakan proyektor sebagai alat media pembelajaran yang kemudian dipraktekkan dalam bentuk latihan pembuatan karya lukis sesuai dengan tema yang diberikan.

Berdasarkan uraian di atas dapat ditarik kesimpulan bahwa proses pembelajaran Seni Lukis I membutuhkan media pembelajaran yang dapat mendukung proses kreatifitasnya sehingga perlu dirancang proses pembelajaran lebih memanfaatkan teknologi mutakhir seperti pemanfaatan teknologi informasi, dan komputer (multimedia) sehingga materi yang ingin disampaikan dapat diterima dengan baik oleh mahasiswa. Sebab multimedia pembelajaran untuk proses pembelajaran identik dengan proses komunikasi. Dengan kata lain media pembelajaran yang dimaksudkan yaitu segala sesuatu yang dapat digunakan untuk menyalurkan pesan dari pengirim ke penerima sehingga merangsang pikiran, perasaan, perhatian dan minat serta kemauan mahasiswa sedemikiana rupa sehingga proses belajar terjadi untuk pencapaian tujuan pembelajaran secara efisien dan efektif.

Proses komunikasi yang terkandung didalamnya terdiri dari beberapa komponen komponen yaitu sumber pesan, pesan, penerima pesan, media, dan umpan balik. Sumber pesan yaitu seseorang yang menyampaikan pesan (dosen). Pesan adalah isi/materi ajar yang tertuang dalam kurikulum yang dituangkan dalam simbol-simbol tertentu (encoding). Penerima pesan yaitu mahasiswa dengan menafsirkan simbol-simbol tersebut sehingga dipahami sebagai pesan (decoding). Sedangkan media yaitu perantara yang menyalurkan pesan dari sumber ke penerima.

Pembelajaran Seni Lukis I perlu untuk memanfaatkan teknologi mutakhir (modern) yang ada, yaitu dengan memanfaatkan media teknologi yang berbasis mikroprosesor untuk membuat dan mempresentasikan materi pelajaran. Salah satu media pembelajaran yang berkembang saat ini dan dapat digunakan pengajar dalam proses pembelajaran adalah media pembelajaran yang memanfaatkan multimedia. Multimedia merupakan penyajian informasi berupa teks, gambar, dan suara secara bersama sehingga menjadi efektif dan efisien".

Multimedia pembelajaran diproduksi dengan memanfaatkan berbagai media yang terintegrasi menjadi satu. Setiap komponen media dapat merangsang satu atau lebih indra 
manusia. Semakin banyak indra yang terlibat dalam proses belajar, maka proses belajar tersebut akan menjadi lebih efektif. Secara tegas hal ini menyarankan penggunaan lebih dari satu indera manusia. Oleh karena itu, pemanfaatan multimedia dalam pembelajaran dapat diharapkan meningkatkan hasil belajar mahasiswa.

Multimedia pembelajaran interaktif dalam proses belajar akan membuat suasana yang berbeda dalam pembelajaran, karena materi yang dulunya diajarkan dengan ceramah dan hanya monoton dapat divariasi dengan menampilkan tayangan berupa integrasi teks, suara, gambar bergerak dalam multimedia interaktif tersebut. Hal ini tentunya membuat mahasiswa akan menjadi tertarik dengan materi diajarkan apalagi mereka dapat memperoleh informasi sesuai dengan pembelajaran yang dibutuhkannya. Dengan kata lain multimedia interaktif dapat bermanfaat untuk meningkatkan motivasi belajar mahasiswa melalui pengembangan dan penciptaan sarana belajar, sumber belajar, serta menunjukkan kemajuan teknologi yang semakin pesat. Multimedia Pembelajaran Interaktif yang akan dihasilkan dapat dijadikan sebagai variasi sarana pembelajaran dan meningkatkan kreativitas serta memotivasi mahasiswa untuk terus belajar supaya dapat memenuhi tuntutan perkembangan zaman.

Melihat kenyataan tersebut, perlu adanya pengembangan media pembelajaran untuk mata kuliah Seni Lukis I. Dengan pengembangan produk Multimedia Pembelajaran Interaktif ini diharapkan dapat membantu dosen dalam menjelaskan berbagai bahasan materi pelajaran. Para mahasiswa sebagai penerima materi pelajaran, akan lebih mudah dalam memahami materi yang disampaikan. Penelitian ini merupakan upaya untuk pengembangan media pembelajaran berupa produk Multimedia Pembelajaran Interaktif Mata Kuliah Seni Lukis I dengan menggunakan program Adobe Flash Professional CS6.

Soedarso (2000: 1) berpendapat bahwa; secara sederhana seni lukis dapat didefenisikan sebagai usaha untuk menciptakan bentuk bentuk yang menyenangkan melalui bidang dua dimensional. Bentuk yang sedemikian itu memuaskan kesadaran keindahan kita dan rasa indah ini terpenuhi kita bila bisa menemukan kesatuan dan harmoni dalam hubungan bentuk bentuk dari kesadaran persepsi kita.
Kemp (1994: 187) mengklasifikasikan media ke dalam beberapa kategori media seperti: (1) Real Things termasuk di dalamnya pembicara tamu, objek dan model yang merupakan stimulasi dari objek sebenarnya, (2) Two Dimensional Display Materials, seperti kertas hasil print atau fotokopi, papan tulis dan flipchart, diagram, chart, gambar, foto, lembar kerja, CD- ROM, dan foto CD, (3) Audio recordings, seperti audiocassette recording dan audio CD recording,(4) Projected Still Pictures, termasuk di dalamnya overhead tranparancies, computer-generated images, slides, dan filmstrips, (5) Projected Moving Pictures, seperti film dan videotape, (6) Combinations of media, yang merupakan gabungan dari beberapa media dan (7) Interactive Technologies, termasuk Computer-Based Instruction (CBI) dan aplikasi multimedia.

Multimedia didefinisikan sebagai penyampaian informasi secara interaktif dan terintegrasi yang mencakup teks, gambar, suara, video atau animasi. Hackbarth (1996) menekankan bahwa hypermedia dan hypertext termasuk multimedia interaktif berbasis komputer. Kellerman \& Meyer (1996 : 8) menyatakan bahwa istilah multimedia lebih terfokus pada interaktivitas antara media dengan pemakai media.

Multimedia pembelajaran interaktif pada Mata Kuliah Seni Lukis I mengikuti karakteristik prinsip-prinsip disain pembelajaran multimedia interaktif dari Susilana \& Riyana (2009) yaitu:

a) Self-Instructiona.Melalui media tersebut mahasiswa mampu membelajarkan diri sendiri, tidak tergantung pada pihak yang lain. Sesuai dengan tujuan media adalah agar mahasiswa mampu belajar mandiri. Untuk memenuhi karakter self instructional maka modul harus: (1) terdapat tujuan jelas yang dirumuskan dengan jelas, (2) terdapat materi pembelajaran yang dikemas ke dalam unitunit/kegiatan spesifik sehingga memudahkan mahasiswa belajar secara tuntas, (3) tersedia contoh dan ilustrasi yang mendukung kejelasan pemaparan materi pembelajaran, (4) terdapat soal soal latihan, tugas dan sejenisnya yang memungkinkan mahasiswa memberikan respon dan mengukur penguasaannya, (5) kontekstual yaitu materi materi yang disajikan terkait dengan suasana atau konteks tugas dan lingkungan mahasiswa, (6) menggunakan bahasa yang sederhana 
dan komunikatif, (7) terdapat rangkuman materi pembelajaran, (8) terdapat instrumen penilaian/assessment, yang memungkinkan mahasiswa melakukan selft assessment, (9) terdapat instumen yang dapat digunakan menetapkan tingkat penguasaan materi untuk menetapkan tingkat penguasaan materi untuk menetapkan kegiatan belajar selanjutnya, dan (10) tersedia informasi tentang rujukan/pengayaan/referensi yang mendukung materi pembelajaran yang dimaksud.

b) Self-Contained. Self contained yaitu seluruh materi pembelajaran dari satu kompetensi atau subkompetensi yang dipelajari terdapat di dalam satu modul secara utuh. Tujuan dari konsep ini adalah memberikan kesempatan mahasiswa mempelajari materi pembelajaran secara tuntas, karena materi dikemas kedalam satu kesatuan yang utuh. Jika harus dilakukan pembagian atau pemisahan materi dari satu kompetensi/sub kompetensi harus dilakukan dengan hati hati dan memperhatikan keluasan kompetensi/sub kompetensi yang harus dikuasai oleh mahasiswa.

c) Stand Alone (berdiri sendiri). Stand alone atau berdii sendiri yaitu media yang dikembangkan tidak tergantung pada bahan ajar lain atau tidak harus digunkan bersama sama dengan bahan ajar lain. Dengan menggunakan media, mahasiswa tidak perlu bahan ajar yang lain untuk mempelajari dan atau mengerjakan tugas pada media tersebut. Jika mahasiswa masih menggunakan dan tergantung pada bahan ajar lain selain media yang digunakan tersebut, maka bahan ajar tersebut tidak dikategorikan sebagai media yang berdiri sendiri.

d) Adaptive. Media hendaknya memiliki daya adaptive yang tinggi terhadap perkembangan ilmu dan teknologi. Dikatakan adaptive jika media tersebut dapat menyelesaikan perkembangan ilmu pengetahuan dan teknologi, serta fleksibel digunakan di berbagai tempat. Media adaptive adalah jika isi materi pembelajaran dan perangkat lunaknya dapat digunakan sampai dengan kurun waktu tertentu.

e) User friendly. Media hendaknya juga memenuhi kaidah user friendly atau bersahabat/akrab dengan pemakainya.
Setiap instuksi dan paparan informasi yang tampil bersifat membantu dan bersahabat dengan pemakainya, termasuk kemudahan pemakai dalam merespon, mengakses sesuai dengan keinginan. Penggunaan bahasa yang sederhana, mudah dimengerti serta menggunakan istilah yang umum digunakan merupakan salah satu bentuk user friendly.

f) Representasi Isi. Pembelajaran interaktif berbasis web tidak sekedar memindahkan teks dalam buku, atau modul menjadi pembelajaran interaktif berbasis web, tetapi materi diseleksi yang betul betul representatif untuk dibuat pembelajaran interaktif berbasis web. Misalnya khusus materi yang perlu terdapat unrus animasi, video, simulasi, demonstrasi dan games, mahasiswa tidak hanya membaca teks tetapi juga melihat animasi tentang sebuah proses menyerupai proses yang sebenarnya, sehingga mempermudah pemahaman dengan biaya yang relatif lebih rendah dibanding langsung pada objek nyata.

g) Visualisasi dengan Multimedia (video, animasi, suara, teks, dan gambar). Materi dikemas secara multimedia terdapat didalamnya teks, animasi, saund dan video sesuai dengan tuntutan materi. Trknologi 2D dan 3D dengan kombinasi teks akan mendominasi kemasan materi, hal ini cukup efektif untuk mengajarkan materi materi yang sifatnya aplikatif, berproses, sulit terjangkau, berbahaya apabila dipraktekkan, memiliki tingkat keakurasian tinggi. Misalnya proses perakitan mesin, proses terjadinya hujan, proses predaran darah pada tubuh, perubahan wujud benda, dan lainnya. Dengan logika yang sama dapat dibuat dengan teknologi animasi.

h) Menggunakan Variasi Menarik dan Kualitas Resolusi Tinggi. Tampilan berupa template dibuat dengan teknologi rekayasa digital dengan resolusi tinggi tetapi support untuk setiap spec sistem komputer. Tampilan yang menarik dengan memperbanyak image dan objek sesuai tuntutan materi, akan meningkatkan ketertarikan mahasiswa terhadap materi pengajaran, tidak membuat jenuh, bahkan menyenangkan

i) Tipe-tipe Pembelajaran Bervariasi. Menawarkan variasi type pembelajaran sesuai dengan kajian teori. Penggunaan tipe ini dapat dirancang secara terpisah 
atau kolaboratif antara beberapa type model pembelajaran, disesuaikan dengan tuntutan materi dan permintaan pembuatan.

j) Respon Pembelajaran dan Penguatan. Pembelajaran interaktif berbasis web memberikan respon terhadap stimulasi yang diberikan oleh mahasiswa pada saat mengoperasikan program. Komputer telah diprogram dengan menyediakan data based terhadap kemungkinan jawaban yang diberikan oleh mahasiswa. Selain itu setiap respon dimungkinkan untuk diberikan penguatan (reinforcement) secara otomatis yang telah terprogram, penguatan terhadap jawaban benar dan salah dari siswa. Reinforcement diberikan untuk meningkatkan motivasi dan ketertarikan mahasiswa pada program.

k) Dapat digunakan Secara Klasikal atau Individual. Pembelajaran interaktif berbasis web dapat digunakan oleh mahasiswa secara individual, tidak hanya dalam setting sekolah, tetapi juga dirumah. Materi dapat diulang ulang sesuai dengan kehendah mahasiswa. Dapat juga digunakan secara klasikal dengan jumlah mahasiswa maksimal 50 orang di ruang komputer, atau kelas biasa, dapat dipandu oleh dosen atau cukup mendengarkan uraian narasi dari narator yang telah tersedia program.

Berdasarkan uraian di atas maka pada penulisan ini akan dibahas pembuatan multimedia pembelajaran interaktif yang memanfaatkan media teknologi yang sedang berkembang pesat yaitu teknologi mutakhir berbasis mikroprosesor. Pembuatan multimedia pembelajaran interaktif merupakan upaya pemecahan masalah pembelajaran Seni Lukis I dengan menggunakan teknologi komputer yang berkembang semakin canggih melalui serangkaian proses disain, produksi, dan evaluasi. Kegiatannya bukan hanya mengembangkan produk multimedia pembelajaran interaktif Seni Lukis I secara terpisah, tetapi juga menyangkut mendisain pembelajarannya, dan pemanfaatannya. Multimedia pembelajaran interaktif Seni Lukis I akan menghasilkan penguatan yang tinggi. Salah satu alat bantu untuk mengembangkan multimedia pembelajaran interaktif adalah program Adobe Flash Profesional CS 6.

Penelitian pengembangan ini adalah untuk menjawab masalah-masalah dalam perumusan masalah di atas menghasilkan media pembelajaran berupa produk Multimedia Pembelajaran Interaktif berdasarkan kriteria kualitas media pembelajaran yang valid serta untuk melihat efektifitas dalam pembelajaran Mata Kuliah Seni Lukis I.

\section{METODE PENELITIAN}

Penelitian ini dilakukan di FBS UNIMED yang terletak di Jalan Willian Iskandar Pasar V Medan pada mahasiswa Jurusan Seni Rupa Semester III. Penelitian pengembangan (Research and Development) ini terdiri dari tiga tahap, di mana langkah-langkah penelitian mengacu pada model pengembangan Borg \& Gall (1983) digabung model pengembangan media Sukiman (2012).

$$
\text { Langkah-langkah dari tahapan }
$$

pengembangannya adalah sebagai berikut: (1) Perencanaan Awal Pengembangan Produk Media Pembelajaran Interaktif; Menganalisis Kebutuhan dan Karakteristik Peserta didik, Merumuskan Kompetensi Hasil Belajar, Pengembangan Materi Pembelajaran, Perumusan Alat Pengukur Keberhasilan, (2) Prototip Produk Media Pembelajaran Interaktif, Pembuatan Naskah/Garis Besar Program Media, Produksi Produk, Prototip Produk; (3) Evaluasi Formatif Produk Media Pembelajaran Interaktif; Evaluasi tahap I (review para ahli), Evaluasi tahap II (Penilaian dan tanggapan perorangan), Evaluasi tahap III (Uji coba Kelompok Kecil).

Instrumen penelitian yang digunakan untuk mendapatkan data adalah berupa pertanyaan pertanyaan yang membutuhkan respon balik sebagai data masukan. Pertanyaan pertanyaan ini diarahkan untuk mengetahui kecepatan pemahaman mahasiswa terhadap materi pelajaran, apresiasi mahasiswa terhadap materi dan eksplorasi mahasiswa dalam menggunakan media pembelajaran interaktif beserta responnya. Instrumen-instrumen tersebut berupa observasi, angket dan wawancara yang tujukan kepada; (1) ahli materi, (2) ahli media, (3) ahli disain pembelajaran, dan (4) mahasiswa.

Untuk mengetahui kemampuan mahasiswa mengenai karya Seni Lukis I dilakukan pre-test dan pos-test. Dimana pre-test dilakukan sebelum media pembelajaran diberikan dan pos-test diberikan sesudah mahasiswa mengenal media pembelajaran. Penelitian tersebut dilakukan oleh peneliti dan dosen bidang studi. Tugas latihan ini dibuat secara bebas dengan menentukan sudut pandang pada lingkungan disekitar aktifitas 
belajar (kampus). Objek, warna, media dan teknik yang dipilih disesuaikan dengan kreatifitas imaginasi demi untuk menghasilkan suatu ekspresi emosi atau sensasi dari dalam jiwa sebagai ungkapan pelukisnya. Menurut Wilson dalam Bloom, Hasting dan Madaus (1971), penilaian untuk tujuan pendidikan Seni Rupa yang juga merupakan kawasan kognitif, afektif dan psikomotor secara berjenjang meliputi perilaku (1) Persepsi, (2) Pengetahuan, (3) Pemahaman, (4) Analisis, (5) Evaluasi, (6) Apresiasi, dan (7) Produksi. Instumen penilaian terhadap karya tugas Seni Lukis I secara umum hendak mengukur kawasan pengetahuan dalam aspek fakta dan kawasan produksi meliputi aspek keterampilan dan kreatifitas dengan rentang nilai 1-100.

Analisis data dilakukan untuk memperoleh pemahaman yang kongkret tentang keberhasilan media pembelajran interaktif yang sudah diproduksi. Hasil yang diperoleh digunakan sebagai bahan pertimbangan dalam memperbaiki multimedia pembelajaran interaktif. Ada dua teknik analisis data yang digunakan untuk mengolah data hasil pengembangan yaitu, analisis isi dan analisis deskriptif. Analisis isi pembelajaran; Analisi isi dilakukan dengan analisis pengelompokan untuk merumuskan tujuan pembelajaran berdasarkan standar kompetensi serta menata materi isi pembelajaran. Hasil dari analisis ini kemudian dipakai sebagai dasar untuk mengembangkan multimedia pembelajaran interaktif. Analisis deskriptif; Pada tahap review, data yang terkumpul dari penyebaran angket akan memberikan kritik, saran, masukan dan perbaikan.

Data-data yang terkumpul dapat dikelompokkan menjadi dua yaitu: data kuantitatif yang berbentuk angka-angka dan data kualitatif yang berbentuk kalimat atau simbol. Data kualitatif yang bersumber dari wawancara dan observasi akan dianalisis secara logis dan bermakna atau secara desriptif naratif, sedangkan data kuantitatif yang bersumber dari angket akan dianalisis dengan deskriptif persentase. Hasil analisis deskriptif ini digunakan untuk menentukan tingkat kelayakan, keberhasilan dan kemenariakan produk pengembangan berupa Multimedia Pembelajaran Interaktif Seni Lukis I. Kelayakan, keberhasilan dan kemenarikan produk Multimedia Pembelajaran Interaktif diketahui melalui hasil analisis kegiatan validitas yang dilaksanakan melalui beberapa tahap, yakni: validitas ahli materi bidang studi, validitas ahli disain pembelajaran, validitas ahli media pembelajaran dan uji perorang dan uji coba lapangan. Berdasarkan kisi kisi instrumen yang telah diuraikan, maka rentang skor dengan skala penilaian 1 sampai 5 yang akan diberikan dimana: 1 = sangat kurang, 2 = kurang baik, $3=$ sedang, 4 = baik dan 5 = sangat baik. Sementara itu untuk pengelolaan data tanggapan hasil uji coba instrumen menggunakan skala Likert dan untuk uji hipotesis dengan dengan uji t.

Tabel 1. Kriteria Persentase Respon

\begin{tabular}{|c|c|l|}
\hline $\begin{array}{c}\text { Persentase } \\
(\%)\end{array}$ & Kualifikasi & \multicolumn{1}{c|}{ Keputusan } \\
\hline $85-100$ & Sangat baik & $\begin{array}{l}\text { Produk baru siap dimanfaatkan di lapangan sebenarnya } \\
\text { untuk kegiatan pembelajaran/tidak revisi }\end{array}$ \\
\hline $75-84$ & Baik & $\begin{array}{l}\text { Produk baru siap dimanfaatkan di lapangan sebenarnya } \\
\text { untuk kegiatan pembelajaran setelah ada revisi kecil }\end{array}$ \\
\hline $65-74$ & Sedang & $\begin{array}{l}\text { Produk dapat dilanjutkan, dengan menambahkan sesuatu } \\
\text { yang kurang, melakukan pertimbangan pertimbangan } \\
\text { tertentu, penambahan yang dilakukan tidak terlalu besar, dan } \\
\text { tidak mendasar. }\end{array}$ \\
\hline $55-64$ & Kurang baik & $\begin{array}{l}\text { Merevisi dengan meneliti kembali secara seksama dan } \\
\text { mencari kelemahan-kelemahan produk untuk } \\
\text { disempurnakan. }\end{array}$ \\
\hline$<54$ & Sangat kurang & $\begin{array}{l}\text { Produk gagal, merevisi secara besar-besaran dan mendasar } \\
\text { tentang isi produk. }\end{array}$ \\
\hline
\end{tabular}

Apabila hasil yang diperoleh sudah dinyatakan sudah dapat dimanfaatkan dengan mencapai kriteria minimal 65\%, maka layak untuk proses pembelajaran Seni Lukis I. multimedia pembelajaran interaktif ini 


\section{HASIL DAN PEMBAHASAN Hasil}

Berdasarkan penilan para ahli yaitu ahli materi, ahli disain pembelajaran dan ahli media pembelajaran pada setiap indikator penilaian mengenai produk yang telah selesai dikerjakan telah diberi nilai dan skor rata rata masing masing oleh para ahli. Kemudian hasil tersebut dianalisis untuk menentukan layak tidaknya dikembangkan media pembelajaran interaktif pada mata kuliah Seni Lukis I.

Adapun persentase rata rata dari hasil penilaian para ahli yaitu ahli materi, ahli disain pembelajaran dan ahli media pembelajaran dapat dilihat pada tabel 2 .

Tabel 2. Persentase Rata-rata Hasil Penilaian Multimedia Pembelajaran Interaktif Mata kuliah Seni Lukis I Oleh Para Ahli

\begin{tabular}{|c|c|c|c|}
\hline No & Para Ahli & Persentase & Kriteria \\
\hline 1 & Materi Pembelajaran & $92,7 \%$ & Sangat Baik \\
\hline 2 & Disain Pembelajaran & $91,8 \%$ & Sangat Baik \\
\hline 3 & Media Pembelajaran & $87,5 \%$ & Sangat Baik \\
\hline \multicolumn{2}{|c|}{ Rata rata } & $90,7 \%$ & Sangat Baik \\
\hline
\end{tabular}

Hasil penilaian para ahli yaitu ahli materi, ahli disain pembelajaran dan ahli media pembelajaran secara keseluruhan menunjukkan tingkat validasi 90,7 \% terhadap media pembelajaran, yang berarti termasuk kategori sangat baik secara keseluruhan. Dengan kata lain media pembelajaran mata kuliah Seni Lukis I dapat memenuhi kebutuhan Pembelajaran. Berikut gambar diagram rata rata persentase hasil penilaian para ahli.

Penilaian perorangan dilakukan pada 3 mahasiswa Semester 3 (ganjil) Jurusan Seni Rupa yang terdiri dari 1 mahasiswa yang memiliki prestasi tinggi, 1 orang yang berprestasi sedang dan 1 orang berprestasi rendah. Tujuan penilaian dan tanggapan ini adalah untuk mengindentifikasi kekurangan produk pembelajaran setelah ditinjau oleh tenaga ahli. Penilaian dan tanggapan ini untuk mendapatkan masukan tentang penyajian produk pembelajaran meliputi aspek kualitas materi pembelajaran dan aspek kualitas teknis atau tampilan yang terdapat dalam DVD Multimedia Pembelajaran Mata Kuliah Seni Lukis I

Tabel 3. Skor Penilaian dan Tanggapan Multimedia Pembelajaran Interaktif oleh Perorangan Tentang Kualitas Pembelajaran dan Teknis Multimedia Pembelajaran (Skala 1-5)

\begin{tabular}{|c|c|c|c|c|c|c|c|}
\hline \multirow{2}{*}{ No } & \multirow{2}{*}{ Indikator Penilaian } & \multicolumn{3}{|c|}{ Responden } & \multirow{2}{*}{$\begin{array}{c}\text { Jumlah } \\
\text { Skor }\end{array}$} & \multirow{2}{*}{$\begin{array}{l}\text { Rata } \\
\text { rata }\end{array}$} & \multirow{2}{*}{ Kiteria } \\
\hline & & 1 & 2 & 3 & & & \\
\hline 1 & Kesesuaian Materi & 4 & 5 & 5 & 14 & 93,3 & Sangat Baik \\
\hline 2 & Kemudahan memahami pembelajaran & 5 & 5 & 5 & 15 & 100 & Sangat Baik \\
\hline 3 & Kejelasan umpan balik & 5 & 5 & 5 & 15 & 100 & Sangat Baik \\
\hline 4 & Kesesuaian tampilan layar & 5 & 5 & 4 & 14 & 93,3 & Sangat Baik \\
\hline 5 & Teks mudah dibaca & 4 & 4 & 5 & 13 & 86,7 & Sangat Baik \\
\hline 6 & Kualitas gambar & 5 & 5 & 4 & 14 & 93,3 & Sangat Baik \\
\hline 7 & Penggunaan tombol navigasi & 5 & 5 & 5 & 15 & 100 & Sangat Baik \\
\hline 8 & Interaksi & 5 & 4 & 5 & 14 & 93,3 & Sangat Baik \\
\hline 9 & Pemutar musik & 4 & 5 & 5 & 14 & 93,3 & Sangat Baik \\
\hline 10 & Pemutar video & 5 & 4 & 4 & 13 & 86,7 & Sangat Baik \\
\hline 11 & Pengaturan musik dan video & 4 & 3 & 5 & 12 & 80 & Sangat Baik \\
\hline \multicolumn{6}{|c|}{ Persentase } & $92,4 \%$ & Sangat Baik \\
\hline
\end{tabular}

Kesimpulan hasil penilaian dan tanggapan perorangan secara keseluruhan maka disimpulkan bahwa persentase nilai rata rata dari indikator tersebut adalah $92,4 \%$. Dimana jika rentang berada pada skor $85 \% \leq \mathrm{X} \leq$
$100 \%$ maka kecenderungan penilaian perorangan dinyatakan kategori "Sangat Baik"

Penilaian dan Tanggapan Lapangan dilakukan pada saat uji coba produk pengembangan media pembelajaran Seni Lukis 
I yang diberikan oleh dosen kepada mahasiswa Jurusan Seni Rupa Semester 3. Tujuan penilaian dan tanggapan ini adalah untuk mengindentifikasi kekurangan produk pembelajaran setelah ditinjau oleh tenaga ahli dan perorangan. Penilaian dan tanggapan ini untuk mendapatkan masukan tentang penyajian produk pembelajaran meliputi aspek kualitas materi pembelajaran dan aspek kualitas teknis atau tampilan yang terdapat dalam CD media pembelajaran mata kuliah Seni Lukis I.

Tabel 4. Skor Penilaian dan Tanggapan Multimedia Pembelajaran Interaktif oleh Mahasiswa Tentang Kualitas Pembelajaran dan Teknis Multimedia Pembelajaran (Skala 1-5)

\begin{tabular}{|c|c|c|c|c|c|}
\hline \multirow[t]{2}{*}{ No } & \multirow[t]{2}{*}{ Indikator Penilaian } & \multicolumn{2}{|c|}{$\begin{array}{c}\text { Skor } \\
\text { Responden }\end{array}$} & \multirow[t]{2}{*}{ Rata rata } & \multirow[t]{2}{*}{ Kiteria } \\
\hline & & 4 & 5 & & \\
\hline 1 & Kesesuaian Materi & 7 & 25 & 95,6 & Sangat Baik \\
\hline 2 & Kemudahan memahami pembelajaran & 6 & 26 & 96,2 & Sangat Baik \\
\hline 3 & Kejelasan umpan balik & 4 & 28 & 97,5 & Sangat Baik \\
\hline 4 & Tampilan layar & 12 & 20 & 92,5 & Sangat Baik \\
\hline 5 & Teks mudah dibaca & 14 & 18 & 91,2 & Sangat Baik \\
\hline 6 & Kualitas gambar & 11 & 21 & 93,1 & Sangat Baik \\
\hline 7 & Penggunaan tombol navigasi & 3 & 29 & 98,1 & Sangat Baik \\
\hline 8 & Interaksi & 13 & 19 & 91,8 & Sangat Baik \\
\hline 9 & Suara pemutar musik & 5 & 27 & 96,8 & Sangat Baik \\
\hline 10 & Suara pemutar video & 10 & 22 & 93,7 & Sangat Baik \\
\hline 11 & Pengaturan musik dan video & 12 & 20 & 92,5 & Sangat Baik \\
\hline & Persentase & & & $94,1 \%$ & Sangat Baik \\
\hline
\end{tabular}

Kesimpulan hasil penilaian dan tanggapan uji coba lapangan dari 32 orang mahasiswa secara keseluruhan maka disimpulkan bahwa persentase nilai rata rata dari indikator tersebut adalah $94,1 \%$. Dimana jika rentang berada pada skor $85 \% \leq \mathrm{X} \leq$ $100 \%$ maka kecenderungan penilaian uji coba lapangan dinyatakan kategori "Sangat Baik"

\section{Pengujian Hipotesis}

$$
\text { Ho }: \mu_{1}=\mu_{2} \quad \text { Ha }: \mu_{1}>\mu_{2}
$$

Keterangan :

$\mu_{1}=$ Rata-rata hasil belajar mahasiswa sesudah menggunakan multimedia interaktif.

$\mu_{2} \quad=$ Rata-rata hasil belajar mahasiswa sebelum menggunakan multimedia interaktif.

Ho = Tidak ada perbedaan hasil belajar mahasiswa sesudah menggunakan multimedia interaktif dari mahasiswa sebelum menggunakan multimedia interaktif.

$\mathrm{Ha}=$ Ada perbedaan hasil belajar mahasiswa sesudah menggunakan multimedia interaktif lebih tinggi dari mahasiswa sebelum menggunakan multimedia interaktif. Hasil pengujian data dengan menggunakan uji t, data perhitungan selengkapnya terdapat pada lampiran 5 . Berdasarkan perhitungan yang dilakukan dihasilkan bahwa $t_{\text {hitung }}>t_{\text {tabel }}$ atau 13,79 $>1,671$ untuk $\mathrm{dk}=62$. Hal ini berarti $\mathrm{Ha}$ diterima dengan harga $t_{\text {hitung }}$ sebesar 13,79 maka dinyatakan ada perbedaan hasil belajar mahasiswa mata kuliah Seni Lukis I yang diberikan media pembelajaran interaktif dibandingkan dengan mahasiswa yang tidak diberikan media pembelajaran interaktif. Berarti Media Pembelajaran Interaktif Mata kuliah Seni Lukis I dinyatakan telah teruji.

\section{Pembahasan \\ Pengembangan Produk}

Penelitian pengembangan produk ini dilakukan untuk menghasilkan suatu produk berupa media pembelajaran interaktif pada mata kuliah Seni Lukis I yang bertujuan untuk meningkatkan proses belajar dan kompetensi mahasiswa. Oleh sebab itu produk pengembangan media pembelajaran interaktif yang telah dikembangkan dengan memperhatikan aspek pembelajaran dan media sebagai prinsip disain pesan pembelajaran. Dimana proses pengerjaannya diawali dengan (a) perencanaan kebutuhan awal yang dilakukan dengan melakukan studi pendahuluan, (b) 
setelah itu, membuat GBPM yang menjadi tolak ukur produksi media, (c) kemudian dilakukan reviuw para ahli materi, disain dan media pembelajaran untuk validasi para ahli, (d) setelah itu, dilakukan pengumpulan penilaian dan tanggapan perorangan, dan (e) langkah terakhir dilakukan uji coba lapangan yang berikan kepada mahasiswa.

Selama evaluasi produk mulai dari reviuw para ahli sampai dengan uji lapangan, beberapa perubahan telah dilakukan terhadap media pembelajaran yang diproduksi. Hal ini dilakukan untuk penyempurnaan produk agar sesuai dengan kebutuhan dan karakteristik pembelajaran mahasiswa. Berdasarkan penilaian dengan menggunakan angket yang diberikan ditemukan bahwa nilai rata rata yang didapat dikategorikan sangat baik. Berikut hasil rangkuman penilaian yang diberikan oleh para ahli materi, disain, media pembelajaran, perorangan dan uji lapangan.

\section{Pembahasan Keefektifan Produk}

Hasil pengolahan data data yang didapat dari uji coba lapangan dinyatakan bahwa media pembelajaran interaktif layak digunakan sesuai dengan kebutuhan dan karakteristik mata kuliah dan mahasiswa sebagai pengguna. Dimana ditemukan ada perbedaan hasil belajar mahasiswa mata kuliah Seni Lukis I yang diberikan media pembelajaran interaktif dibandingkan dengan sebelum mahasiswa diberikan media pembelajaran interaktif. Perbedaan ini menunjukan hasil belajar mahasiswa yang diberikan media pembelajaran interaktif lebih tinggi dibandingkan dengan sebelum mahasiswa diberikan media pembelajaran. Hal ini dapat dilihat dari hasil pengujian dengan menggunakan uji $\mathrm{t}$, diperoleh harga $\mathrm{t}_{\text {hitung }}=$ 13,79 dan $t_{\text {tabel }}=1,671$. Jika dibandingkan ternyata $t_{\text {hitung }}>t_{\text {tabel }}$ atau $13,79>1,671$, dengan diperolehnya harga $t_{\text {hitung }}$ sebesar 13,79. Juga dapat dilihat dari hasil nilai rata-rata mata kuliah Seni Lukis I mahasiswa yang diajar dengan multimedia interaktif yaitu sebesar $87,16 \%$, sedangkan hasil nilai rata-rata mata kuliah Seni Lukis I mahasiswa yang diajar tanpa multimedia interaktif sebesar $69.65 \%$. Maka dapat dinyatakan bahwa terdapat perbedaan hasil pembelajaran Seni Lukis I antara sebelum dan sesudah mahasiswa menggunakan produk media pembelajaran interaktif. Data data ini menunjukkan bahwa pembelajaran yang menggunakan media pembelajaran interaktif lebih baik dalam meningkatkan kompetensi dan pengetahuan mahasiswa pada mata kuliah Seni Lukis I. Berarti Multimedia Pembelajaran Interakti Seni Lukis I telah teruji. Hal ini sesuai dengan pendapat pakar dan hasil penelitian yang relevan sebagai berikut.

1. Pemberian pengantar materi yang dipresentasikan terlebih dahulu dan berada pada tingkat observasi yang tertinggi, dimana dapat menjelaskan, mengintegrasikan dan menghubungkan materi baru dengan materi yang telah dimiliki sebelumnya dalam struktur kognitif mahasiswa. Seperti yang diungkapkan oleh Ausabel (dalam Joyce \& Weil, 1980:82) menjelaskan bahwa: advance organizer are the primary means of strengthening cognitive structure and enhancing retention of new information. Ausubel describes Advance Organizers as introductory material presented ahead of the learning task end or a higher level of abstarction and inclusiveness than the material in the learning task with previously learned material (and also help the learner discriminate the new material from previously learned material). the most effective organizer are those that use concepts, terms and propositions that are already familiar to the learner, as well as appropriate illustration and analogies.

2. Pengantar materi merupakan media pembelajaran dimana berfungsi sebagai alat penyampaian pesan. Sebagai alat, media sangat perlu dirancang untuk kepentingan pencapaian pembelajaran. Menurut Sukiman, (2012 : 31) menjelaskan stimulus visual membuahkan hasil belajar yang lebih baik untuk tugas tugas seperti mengingat, mengenali, mengingat kembali, dan menghubunghubungkan fakta dan konsep. Sedangkan multimedia dibuat untuk meningkatkan motivasi belajar melalui pengembangan dan penciptaan sarana belajar, sumber belajar, serta menunjukkan kemajuan teknologi yang semakin pesat. Media pembeljaran yang dihasilkan dijadikan sebagai variasi sarana pembelajaran dalam meningkatkan kreativitas serta memotivasi belajar untuk tuntutan perkembangan zaman.

3. Hasil penelitian yang relevan. Hasil penelitian tentang Pengembangan Media Pembelajaran Interaktif Berbasis Komputer Pada Mata Kuliah Menggambar 
Teknik yang dilakukan oleh Nur Basuki, menyimpulkan bahwa media pembelajaran interaktif berbasis komputer dapat, meningkatkan hasil belajar menggambar teknik yang ditunjukkan dengan adanya perbedaan skor yang signifikan antara sebelum dan sesudah penggunaan media pembelajaran interaktif berbasis komputer di Jurusan Pendidikan Teknik Mesin Universitas Negeri Medan.

Digunakannya

Multimedia Pembelajaran Interaktif ini sebagai bagian proses pembelajaran mata kuliah Seni Lukis I akan dapat memberi dampak positif bagi kemampuan mahasiswa dalam proses menciptakan karya lukis tugas yang diberikan. Penguasaan materi dengan latihan yang diberikan akan meningkatkan pengalaman mahasiswa dalam melukis I seperti (1) pemilihan media dan tehnik lukis sesuai denga karakter dan kemampuan mahasiswa masing masing (2) pengolahan bentuk bentuk secara spontan tanpa mengabaikan proporsinya, (3) menggunakan dan mencampur warna sesuai dengan karakter dan sifatnya, (4) menyusun komposisi, keseimbangan, irama dan tone pada bidang kanvas, (5) mengekspresikan kreatifitas dengan cara mempelajari dan membandingkan, (6) menyelasaikan lukisan sampai dengan pembingkaian, dan (7) mengapresiasi karya lukis lainnya dalam diskusi karya sebagai upaya meredahkan sifat ego pribadi.

Melalui media pembelajaran interaktif ini juga dapat membuat dosen lebih bebas melakukan interaksi dengan mahasiswa sehingga proses pembelajaran lebih bersifat interaktif sehingga pembelajaran lebih terfokus pada informasi yang sedang dipelajari ataupun ketidak jelasan mahasiswa akan sesuatu hal mengenai Seni Lukis I. Apalagi pada mata kuliah Seni Lukis I ini mahasiswa dituntut untuk mampu menyerap suatu objek pandang menarik yang berada dilingkungan belajar dan kemudian merepresentasikannya pada bidang kanvas sesuai ekspresi imaginasi dan kreatifitas teknik yang dimilikinya.

Berdasarkan uraian hasil penelitian di atas dapat disimpulkan bahwa produk media pembelajaran interaktif memiliki beberapa kegunaan dan manfaat dalam penggunaannya.

1. Mahasiswa dapat lebih mudah memahami materi pembelajaran karena konsep yang ditawarkan memang untuk mempermudah mahasiswa dalam penguasaan kompetensi.
2. Mahasiswa dapat mengatur pencapaian kompetensi sesuai dengan kecepatan daya serap kreatifitas masing masing.

3. Mahasiswa lebih dapat mengembangkan kreatifitasnya dalam penciptaan karya lukis tugas sebab media pembelajaran ini dilengkapi dengan video proses berkarya beberapa pelukis profesional.

4. Produk media pembelajaran interaktif ini dapat digunakan sebagai media pembelajaran di dalam kelas maupun secara mandiri.

\section{PENUTUP \\ Simpulan}

Kesimpulan yang diperoleh dari hasil penelitian pengembangan Media Pembelajaran Interaktif Seni Lukis I sebagai berikut:

1. Hasil penelitian ini adalah terciptanya Media Pembelajaran Interaktif Seni Lukis I dalam bentuk keping DVD. Media pembelajaran ini dilengkapi dengan teks penjelasan materi, dan video peraga. Media pembelajaran ini dapat digunakan pada PC atau laptop, untuk menggunakan produk ini dapat dilakukan tanpa menginstall program flash terlebih dahulu karena file utama disajikan dalam ekstensi (.exe).

2. Pengembangan media ini dilakukan dalam tiga tahap. (a) perencanaan awal pengembangan produk multimedia interaktif, proses pada bagian ini berfokus pada menganalisis kebutuhan dan karakteristik mahasiswa, merumuskan kompetensi hasil belajar, pengembangan materi pembelajaran, dan perumusan alat pengukur keberhasilan, (b) prototip produk media pembelajaran interaktif, proses pada bagian ini berfokus pada pembuatan naskah / garis besar program produk, produksi produk, dan prototip produk, (c) evaluasi formatif produk multimedia interaktif, bagian dari evaluasi berfokus pada proses pengembangan berlangsung.

3. Hasil penelitian menunjukkan bahwa produk multimedia interaktif untuk pembelajaran mata kuliah Seni Lukis I ini telah selesai dikembangkan dalam bentuk DVD program pembelajaran sesuai dengan prosedur pengembangan. Secara umum 
kualitas produk multimedia interaktif ini termasuk dalam kriteria sangat baik dan juga terdapat perbedaan yang signifikan dari hasil belajar Seni Lukis I antara sebelum dan sesudah mahasiswa menggunakan produk media pembelajaran interaktif.

\section{Saran}

Berdasarkan hasil temuan yang telah diuraikan pada kesimpulan serta implikasi hasil penelitian, berikut ini diajukan beberapa saran yaitu:

1. Mengingat selama ini proses pembelajaran masih bersifat konvensional dan belum adanya bahan ajar sebagai acuan pembelajaran, maka disarankan agar Multimedia Pembelajaran Interaktif Seni Lukis I digunakan karena produk ini mampu memberi umpan balik yang lebih baik bagi mahasiswa.

2. Disarankan kepada dosen agar memberi motivasi kepada mahasiswa untuk belajar mandiri dengan menggunakan Multimedia Pembelajaran Interaktif, karena mahasiswa akan mendapatkan informasi yang mereka inginkan melalui produk ini dan mereka juga tidak perlu tergantung pada kehadiran dosen dalam upaya meningkatkan hasil belajarnya.

3. Mengingat hasil kesimpulan dalam penelitian ini masih memungkinkan dipengaruhi oleh faktor-faktor yang belum mampu terkontrol, maka masih perlu kiranya dilakukan penelitian lebih lanjut pada sampel yang lebih representatif.

\section{DAFTAR PUSTAKA}

Arsyad, A. (2011). Media Pembelajaran. Jakarta: Rajawali Pers.

Borg, W, R, \& Gall, M, D, (1983). Educational Research, An Introduction. New York and London. Longman Inc.

Cottrell, S. (1999). "The Study Skills Handbook". New York: Palgrave.

Cross, A. (1984). Towards an understanding of intrinsic values of design education. London: Design Studies
Gay, L, R, (1987). Educational Research: Competencies for Analysis and Application. Colombus : Merrill

Hamid, A. (2009), Teori Belajar dan Pembelajaran, Medan

Handoyo, C, B. (2010). Penelitian Pendidikan. Yogyakarta : Kanwa Publisher.

Hergenhahn, B.R, (2009), Theories of Learning, Jakarta: Prenada Media Group

Jonathan, S. (2007). Metode Riset Untuk Desain Komunikasi Visual, Yogyakarta: Penerbit Andi.

Joyce, B. \& Weil, M. (1980). Models of Teaching. Second Edition. Englewood New Jersey: Prentice-Hall,Inc.

Kellerman, A. S. \& Meyer, M. J. (1996). Multimedia in the classroom. Boston: Allyn and Bacon

Miarso, Y. (2007). Menyemai Benih Teknologi Pendidikan. Jakarta: Kencana.

Musfiqon. (2012). Pengembangan Media dan Sumber Pembelajaran. Jakarta: Prestasi Pustakaraya.

Nusa, P. (2011). Research and Development. Penelitian dan Pengembangan: Suatu Pengantar. Jakarta: Raja Grafindo Persada.

Richard, E, M. (2009). Multimedia Learning. Prinsip Prinsip dan Aplikasi. Yogyakarta: Pustaka Belajar.

Sadiman, A, S, dkk. (1996). Media Pendidikan. Jakarta : Raja Grafindo Persada. (2005). Media Pendidikan. Jakarta: PT Raja Grafindo Persada.

(2010). Media Pendidikan. Pengertian Pengembangan dan Pemanfaatannya. Jakarta: Rajawali Pers.

Sanjaya, W. (2008). Perencanaan dan Desain SistemPembelajaran. Edisi Pertama. Jakarta: Kencana Prenada Media Group.

Sardiman. (2007). Interaksi dan motivasi belajar mengajar. Raja Grafindo Persada. Jakarta

Susilana, R \& Riyana, D. (2009). Media Pembelajaran. Hakekat Pengembangan Pemanfaatan Penilaian. Bandung: Wacana Prima.

Suheri, A. (2006). "Animasi Multimedia Pembelajaran". Jurnal Teknik Informatika Sekolah Tinggi Sains dan Teknologi Indonesia (ST-INTEN) Bandung.

Sukiman. (2012). Pengembangan Media Pembelajaran. Yogyakarta: Pedagogia.

Suparman, A. (2012). Desain Instruksional Modern. Panduan Para Pengajar \& 
Inovator Pendidikan. Jakarta: Erlangga.

Soekamto, \& Winataputra. (1995). Teori Belajar Model Model Pembelajaran. Jakarta: PAU-PP AI Universitas Terbuka Soedarso, (2000). Arti dan Problematik Seni, Yogyakarta: Duta Wacana.
Wahid, F \& Dirgahayu, T. (2012). Pembelajaran Teknologi Informasi di Perguruan Tinggi. Perspektif dan Pengalaman. Yogyakarta: Graha Ilmu. Yamin, M. (2008). Paradigma Pendidikan Konstruktivistik. Jakarta: Gaung Persada Press. 